\title{
EFFECTS OF FOOD PRACTICAL ON STUDENTS SKILLS ACQUISITION IN SELECTED TERTIARY INSTITUTIONS, OGUN STATE, NIGERIA
}

\author{
Adebisi T.T., Babayeju, A. A. and Gbadebo, C. T. \\ Department of Home Economics and Food Sciences \\ Faculty of Agriculture, University of llorin. \\ P.M.B. 1515, llorin, Kwara State, Nigeria \\ adebisitunrayo@yahoo.co.uk/+2348050324198 \\ babayejuadeshola@gmail.com/+2348052061205 \\ christy24ng@yahoo.com/+2348065982341
}

\begin{abstract}
The study examined the effects of Food Practical on students' skill acquisition in selected tertiary institutions in Ogun State. The study focused on Home Economics Students from Tai Solarin University, ljegun, ljebu - Ode and Home and Hotel Management Students of Olabisi Onabanjo University, Yewa Campus, Ayetoro respectively. Two null hypotheses were formulated and tested at 0.05 level of significance. The study was a quasi-experimental at research which employed the pre-test, post-test control group design. The population was made up of three hundred (300) level Home Economics Students in 2014/2015 session and 138 samples were purposively selected. They are grouped into two experimental and control groups: Students from Tai Solarin University (69) and the Control group students from Olabisi Onabanjo University (69). The two groups were subjected to post - test for two weeks. Questionnaire and Evaluation Instrument for practical were used. The data collected were analyzed using Mean, Standard Deviation and Analysis of Covariance (ANCOVA). The F value results of the study revealed that the two null hypotheses were rejected. Findings showed that respondents from control group had better skill acquisition competencies compared to the experimental group. It also revealed that there was a significant difference in the performance of respondents from middle, low and high socio-economic backgrounds. In conclusion, it is very important to expose students to food practical for skill acquisition.
\end{abstract}

Keywords: Effect, Food Practical, Skills acquisition \& tertiary institutions.

\section{INTRODUCTION}

The philosophy of Home Economics Education borders on the improvement of the quality of life of the individual, family and the society at large. It focuses on the acquisition of knowledge, skills and competencies which family members require to satisfactorily improve family living. Food and Nutrition is a major area of Home Economics. It comprises of the principles of nutrition-meal management vis-à-vis practical application of the principles. It is a practical-oriented aspect of Home Economics. The Science of Food and Nutrition cannot be effectively taught without carrying out practical (Adebisi, Opaleke and Unomah 2015). Without agriculture, Food cannot exist, therefore agriculture is the most important sector of the Nigeria economy. It once contributed over 60 per cent of gross domestic products. According to Akinleye and Rahji (2006), the percentage contributions of agriculture fall drastically since independence in the 1960. Department for International Development (2004) stressed further that this decline is also attributed to the boom in the petroleum for continuity in agriculture cum food production, practical learning and awareness of its importance must be emphasized since no nation survives without agriculture. Learning is the activity one performs and the experience(s) one passes through that affect his/her behaviour Oniyama and Amroma - Asite (2008) posited that learning is a progressive and an orderly change in behaviour which comes as a result of experience and exercise. They asserted that learning is acquired through practice or training and experience(s) that must result in change in behaviour and such change in behaviour should be relatively permanent. To this end, various methods of teaching should be employed in learning such as problem solving, role-playing, project, assignment, field trip and mode to 
develop creativity (Ochonogor \& Onyebueke, 2003). Food and Nutrition is a practical-oriented subject which should be taught especially with practice and drill methods. These methods comprise of description and explanation as well as practice. The objectives of the instruction in this method of teaching specify acquisition of skills and proficiencies in performing some acts, the skills to be acquired as part of the components of the subject.

Food processing as explained by Ode, Babayeju, and Obalowu (2012) helps to train students to convert raw food and other farm produce into edible, usable and palatable form, helps to store perishable and semi-perishable agricultural commodities, avoid excess in the market, check post-harvest losses and make the produce available during off-season, generates employment, development of "ready-toconsume" products, saves time for cooking and helps in preservation thus making food safe for consumption. Practical food processing is cited in Ademola and Olaoye (2014) who reported from Ogunleye and Awogbemi (2002) that food processing is very vital and in production of locust beans, the best quality of fermented locust beans are drying and salting. The two methods of fermented locust beans condiment is highly important in marketing strategy. This condiment is good in both adults and children diets. Furthermore, snacks that are traditionally or conventionally produced through food practical are also important for toddlers and preschoolers in food consumption because their stomach is still smaller and therefore need to keep their energy level high. It is through this practical procedures that the skill and principles will be acquired by the student.

In addition, cheese is an excellent source of protein, fat and minerals such as calcium and phosphorous, vitamins and essential amino acids. It is an important food in the diet of both young and old (Olashina and Jadesimi, 2012). It is through food practical skill acquisition that foods can be fortified to improve the nutritional composition. Balogun, Kolawole, Joseph, Adebisi and Ogunleye (2016) explained that utilization of coconut milk in cheese making can also be used during practical to enhance the nutritional composition of cheese. When students are expose to various food practical in schools, they will be able to use the acquired skill to stand the test of time and get a way out for sustainable living (Kembe, 2014).

There have been many calls for nutrition education to prevent obesity and overweight. However, focusing on nutrition knowledge transmission alone is not the answer to gain control over individual's diet and food intake. Lang and Caraher (2001) determined that mastery of food and cooking skills is necessary for a full understanding of what constitutes a healthy life and without practicals, first-hand experience in preparing foods and learning about nutrition, choice and control are weakened and dependence on processed and fast food emerges. Igunnu and Gbadebo (2012) posited that Home Economics and Foods and Nutrition courses provide the only opportunity for students to learn about nutrition and healthy eating through the 'hands-on' food preparation that is recognized as more effective in changing behaviour than knowledge transmission.

As a learner-centered method of teaching in all food practical, the learners are expected to be involved with the practice to develop skills as it provides opportunity for the individual students to participate in the lesson until he masters a particular skill (Oniyama and Amroma - Asite, 2008). This can be done by exposing the acquired skills in the imparting Food and Nutrition skills to the students. There are other variables which may affect skill acquisition even when the curriculum is effectively implemented. These are attitude and socio-economic background of students. Socio-economic background of students could have positive or negative effect on the academic performance of students. This is because the family background and context of a child affect his reaction to life situations and his level of performance. (Ajila and Olutola, 2000).

Parenting practices have significant effects on a child's social and cognitive outcomes. Preparing youth to become caring, competent parents may be the single most effective way to prevent child abuse and 
other violence, increase mental health, advance school preparedness, and achieve academic success for future generations. (Igunnu et al, 2012). According to Okioga (2013) student social economic background influenced their academic performance since Education plays a major role in skill sets for acquiring jobs, as well as specific qualities that stratify people with higher and lower social economic status. He reiterates that the middle class parents take an active role in their children's education and development by using controlled organized activities and fostering a sense of entitlement through encouraged discussion but that families with lower income do not participate in this movement, causing their children to have a sense of constraint. Lower income families can have children who do not succeed to the levels of the middle income children because middle income children have a greater sense of entitlement, more argumentative, or better prepared for adult life. It is against this background that the study wants to find out if students in tertiary institutions are exposed sufficiently to food practical and as such, the practical will have positive effect on their skill acquisitions.

The specific objectives are to:

i. Assess the effect of skill acquisition between students exposed to food practical and those who were not in the study area.

ii. Examine the effects of skill acquisition among students from low, middle and high economic backgrounds in the study area

Research hypotheses are stated in null form and tested at 0.05 level of significance. These are:

$\mathrm{HO}_{1}$ : $\quad$ There is no significance different between skill acquisition of students exposed to food practical and those who were not.

$\mathrm{HO}_{2}$ : There is no significant difference among skill acquisition of students from low, middle and high socio-economic backgrounds.

\section{MATERIALS AND METHODS}

The study was quasi-experimental research which employed the pre-test, post-test control group design. The population consisted of 300 Level Home Economics students in Tai Solarin University, ljagun, ljebuode and Home and Hotel Management Students of Olabisi Onabanjo University, Yewa Campus, Ayetoro, Ogun State in 2014/2015 session. One hundred and thirty - eight (138) students were used as sample. Two instruments were used for data collections. One is the practical skill rating scale that was used for eight weeks. The contents are:

Week 1: Meal Planning and Management

Week 2: Flours and Flour Mixtures-Cake making

Week 3: Pastry making

Week 4: Bread making

Week 5: Meal service

Week 6 Menu Planning

Week 7: Meal Preparation using various food items from the food groups

Week 8: Meal preparation.

The second instrument was questionnaire. The data collected was analyzed using Mean, Standard Deviation and Covariance (ANCOVA). These were tested at 0.05 probability level using Computer subprogram (SPSS). 


\section{RESULTS}

Table 1: Mean score of skill competencies between respondents exposed to food practical and those who were not

\begin{tabular}{lllllllll}
\hline & Group & $\mathbf{N}$ & $\begin{array}{l}\text { Pre-test } \\
\text { Mean }\end{array}$ & $\begin{array}{l}\text { Pre- } \\
\text { test } \\
\text { SD }\end{array}$ & $\begin{array}{l}\text { Post- } \\
\text { test } \\
\text { Mean }\end{array}$ & $\begin{array}{l}\text { Post- } \\
\text { test } \\
\text { SD }\end{array}$ & Gain & Decision \\
\hline $\begin{array}{l}\text { Experimental } \\
\text { Control }\end{array}$ & 1 & 69 & 16.4030 & 1.7326 & 33.3731 & 2.9276 & 16.9701 & \\
Total & 2 & 69 & 15.6620 & 28483 & 18.1690 & 1.5674 & 2.5070 & $\mathrm{~S}$ \\
\hline
\end{tabular}

Table 1 indicated the mean scores of skill competencies between respondents exposed to food practical and those who are not. The findings showed that respondents exposed to food practical had better skill acquisition competencies than those that are not. Experimental group had a post-test mean 33.3731 while the control group had a post-test mean of 18.1690. The post-test gain (16.9701) for the experimental group was far greater than that of the control group (2.5070). The result revealed that there was a significant difference in skill acquisition between students exposed to food practical and those who were not.

Table 2: Mean score of skill acquisition among respondents from socio-economics background.

\begin{tabular}{|c|c|c|c|c|c|c|}
\hline \multirow{2}{*}{\multicolumn{2}{|c|}{ Variable and category }} & \multirow[b]{2}{*}{$\mathbf{N}$} & & & \multicolumn{2}{|r|}{$N=138$} \\
\hline & & & SD & $\overline{\mathbf{X}}$ & Grad Mean & Mean of Means \\
\hline \multirow[t]{2}{*}{ Group } & Experimental & 69 & 3.4668 & 17.8451 & & \\
\hline & Control & 69 & 2.5641 & 17.3881 & & \\
\hline \multirow[t]{3}{*}{ Socio-economic } & Low & 14 & 6.4829 & 22.79 & & \\
\hline & Middle & 77 & 8.1923 & 27.58 & & \\
\hline & High & 47 & 7.1291 & 23.04 & 3.0595 & 17.6232 \\
\hline
\end{tabular}

Table 2 revealed the mean scores of 17.8451 for the experimental group and 17.3881 for the control group which showed that there was no significant difference in the skill acquisition among the respondents. However, when broken down to different socio-economic backgrounds the data revealed respondents from lower socio-economic background are 14 and had a mean score of 22.79 while 77 respondents from middle socio-economic group had a mean score of 27.58 and 47respondents from high socio economic group had a mean score of 23.04. The result showed that there was a significant difference in the performance of respondents from middle socio-economic background who have higher mean than respondents from low and high socio-economic background. 


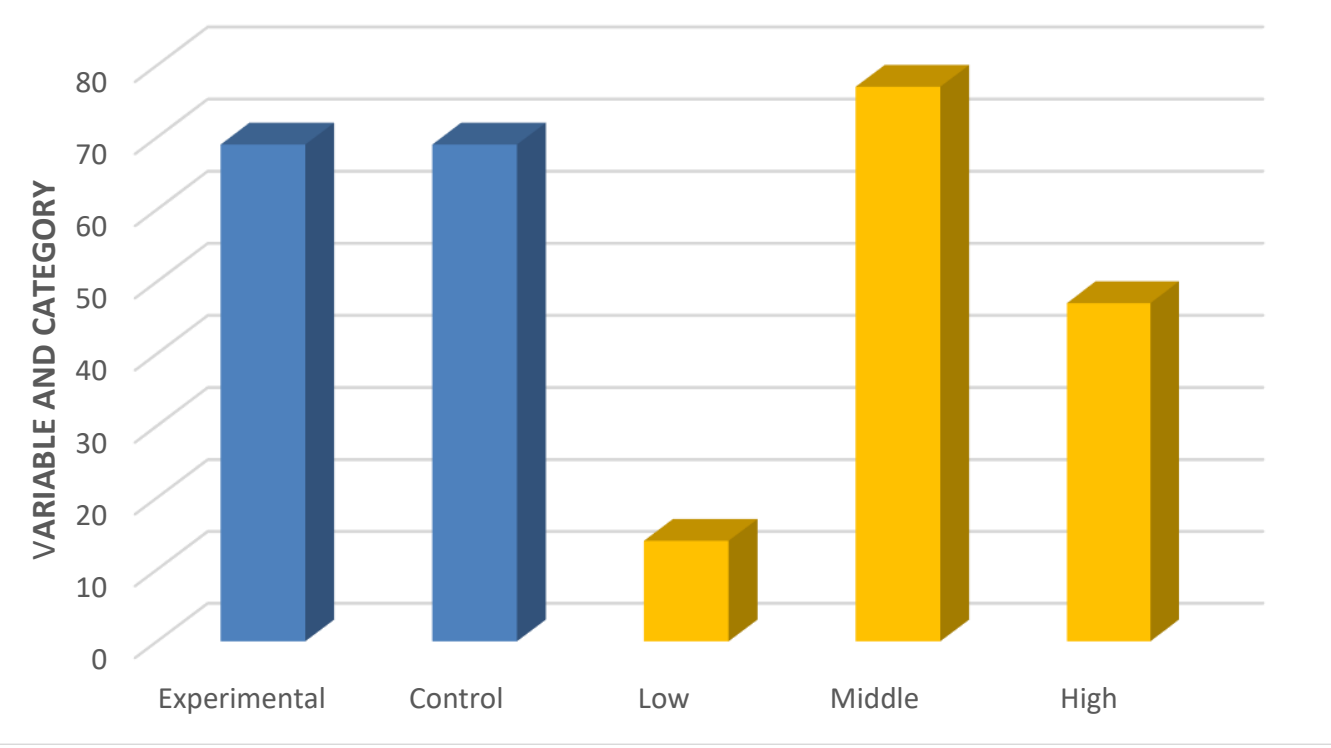

Fig 1: Skill acquisition among respondents from socio-economic background

Fig 1 revealed the mean scores of skill acquisition among respondents from low, middle and high socioeconomic background of both experimental and control groups. The full explanation is in table 2.

Key: 2014/2015 Session of 300 level Home Economics Students

\begin{tabular}{|l|l|l|l|}
\hline Value & Groups & Name of University & Anonymous Name \\
\hline 1 & Experimental & $\begin{array}{l}\text { Tai Solarin Univeristy of Education, ljagun, ljebu- } \\
\text { Ode; 300 Level of 2014/2015 Session of Home } \\
\text { Economics }\end{array}$ & A \\
\hline 2 & Control & $\begin{array}{l}\text { Olabisi Onabanjo University Yewa Campus } \\
\text { Ayetoro. 300 level of 2014/2015 Session of } \\
\text { Home Mgt Dept }\end{array}$ & B \\
\hline
\end{tabular}

Table 3: ANCOVA summary table for the experimental and control groups on skill Acquisition of students exposed to food practical and those who were not

\begin{tabular}{|c|c|c|c|c|c|}
\hline $\begin{array}{l}\text { Source of } \\
\text { variation }\end{array}$ & $\begin{array}{l}\text { Sum } \\
\text { squares }\end{array}$ & of $\mathrm{Df}$ & Mean square & Calculated f-value & Significance \\
\hline Covariates & 252.677 & 1 & 252.677 & 46.511 & 0.000 \\
\hline Pre-test & 252.677 & 1 & 252.677 & *46.511 & 0.000 \\
\hline Main effects & 7720.064 & 1 & 7720.064 & 1421.055 & 0.000 \\
\hline Group & 7720.064 & 1 & 7720.064 & *1421.055 & 0.000 \\
\hline Explained & 7972.7400 & 2 & 3986.370 & 733.783 & 0.000 \\
\hline Residual & 733.405 & 135 & 5.433 & & \\
\hline Total & 8706.145 & 137 & 63.549 & & \\
\hline
\end{tabular}

The results using pre-test as a covariate in table 3 showed that the main effects were significant level at 0.05. This indicated that there was a significant difference between students exposed to food practical and those who were not $(F 1,137=1421.055, P<0.05)$. 
Table 4a: ANCOVA result for the experimental and control groups (independent variables) on skill acquisition of respondents from low, middle and high socioeconomic backgrounds

\begin{tabular}{|c|c|c|c|c|c|}
\hline $\begin{array}{l}\text { Sources of Variation } \\
\text { Covariates }\end{array}$ & $\begin{array}{l}\text { Sum } \\
\text { squares }\end{array}$ & Df & Mean square & Cal F-value & Sig of $F$ \\
\hline Pre-test & 252.677 & 1 & 252.677 & 4.3480 & .039 \\
\hline Main Effects & 665.774 & 2 & 332.887 & 5.7280 & .004 \\
\hline Socio-economic status & 665.774 & 2 & 332.887 & *5.7280 & .002 \\
\hline Explained & 918.450 & 3 & 306.150 & 5.2680 & \\
\hline Residual & 7787.695 & 134 & 58.117 & & \\
\hline Total & 8706.145 & 137 & 63.549 & & \\
\hline
\end{tabular}

$\mathrm{P}<0.05$ Calculated f-value $=5.7280$

Table 4a revealed that the socio-economic status of parents was significant at 0.05 level $(P<0.05)$. The table shows an F-value of 5.7280 and a p-value of 0.002 . Since the $p$-value is less than the alpha level of $0.05(P<0.05)$, the null hypothesis which states that there is no significant difference in skill acquisition among students from low, middle and high socio-economic background is therefore rejected. This means that the socio-economic status of parents had significant effect on the skill acquisition of the respondents $(F 2,137=5.728, P<0.05)$.

Table 4b (i): ANOVA for the Socio-economic background on skill acquisition

\begin{tabular}{llllll}
\hline Sources of variation & Df & Sum of squares & Mean square & F-Ratio & Probability \\
\hline Between Groups & 2 & 721.1716 & 360.5858 & 6.0963 & 0.0029 \\
Within Groups & 135 & 7984.9733 & 59.1480 & & \\
Total & 137 & 8706.1449 & & & \\
\hline
\end{tabular}

Table $4 b$ (i) shows an F-value of 6.0963 and a p-value of 0.0029 . Since the $p$-value is less than the alpha level of $0.05(P<0.05)$, the null hypothesis which states that there is no significant difference in skill acquisition among students from low, middle and high socio-economic background is therefore rejected. Consequently, there is a significant difference in skill acquisition among students from low, middle and high socio-economic backgrounds.

Table 4b (ii) Post HOC Analysis (Turkey's B Multiple Range test) for the Socio-economic background on skill acquisition

\begin{tabular}{lllllll}
\hline & Group & Count & Mean & $\begin{array}{l}\text { Standard } \\
\text { Deviation }\end{array}$ & Standard Error & 95pct cont. int for mean \\
\hline 1 & Low & 14 & 22.7837 & 6.4829 & 1.7326 & 19.0426 to 26.5288 \\
2 & Middle & 77 & 27.5844 & 8.1923 & 9336 & 25.7250 to 29.4438 \\
3 & High & 47 & 23.0426 & 7.1291 & 1.0399 & 20.9494 to 25.1357 \\
& Total & 138 & 25.5507 & 7.9717 & .6786 & 24.2088 to 26.8926 \\
\hline
\end{tabular}

In order to find out groups that are significantly different, the Turkey Post Hoc Analysis was carried out as shown in tables 4 bii. The result indicated that there was a significant difference between respondents from middle class (27.5844) and those from low class (22.7837) and high class (23.0426). The mean score for the middle socio-economic status of parents has significant effect on the skill acquisition of the respondents and respondents from the middle socio-economic group performed better than those from low and high socio-economic group. Therefore, the hypothesis which stated that there is no significant difference in skill acquisition among students from low, middle and high socio-economic backgrounds is therefore rejected. 


\section{DISCUSSION}

The findings showed that the respondents that are exposed to food practical had better skill acquisition competencies than those that are not. This is in line with Oniyama and Amoma-Asite (2008) who posited that learning is the activity one performs and the experience one passes through that affects his/her behaviour. Adebisi et al (2015) explained further that Food and Nutrition is a practical-oriented subject which should be taught especially with practice and drill method. These methods comprise of description and explanation as well as practice. This method of teaching specific acquisition of skills and proficiencies in performing the skills to be acquired as parts and components of the subject. The result revealed that there was a significant difference in skill acquisition between students exposed to food practical and those who were not. This corroborates Olashina and Jaelesimi (2012) who asserted that through food practical skill acquisition, the knowledge can be transferred to improve the nutritional composition. The result also agrees with Kembe (2014) who explained further that when students are exposed to various food practical in schools, they will be able to use the skill acquired to stand the test of time and get sustainable living. Balogun et al (2016) explained further that utilization of coconut milk in cheese making can improve the nutritional composition of cheese.

The result also shows there is a significant difference in skill acquisition among students from low, middle and high socio-economic backgrounds. The result of Turkey Post HOC Analysis also showed that there was a significant difference in the performance of respondents from middle, low and high socio-economic background as respondents from the middle socio-economic group performed better in their mean score than those from low and high socio-economic group.

This finding agreed with the study of Ajila and Olutola (2000) and Okioga (2013) whose studies revealed that the students' social economic background influenced their academic performance and that the middle class parents take an active role in their children's education and development by using controlled organized activities and fostering a sense of entitlement through encouraged discussion but that families with lower income do not participate in this movement, causing their children to have a sense of constraint. Kembe (2014) explained that without agriculture, food cannot exist. Therefore, agriculture is the most important sector of the economy. It once contributed over 60 percent of gross domestic products. According to Akinleye and Raji (2006), for continuity in Agriculture, food production, practical learning and awareness of its importance must be emphasized since no nation can truly survive without agriculture.

\section{CONCLUSION AND RECOMMENDATIONS}

Conclusively, exposure of students to food practical is necessary for skill acquisition. Food processing helps to train students to convert raw food and other farm produce into edible, usable and palatable forms. Foods and Nutrition courses provide the only opportunity for students to learn about nutrition and healthy eating through the "hands-on" food preparation that is recognized as more effective in changing behaviour than knowledge transmission. In addition, the socio-economic background of students had no bearing with their skill acquisition.

Therefore, this study recommends that different methods of teaching should be employed to develop creativity among the students. The respondents from the three socio-economic status should put in all their best in skill acquired because they believe that "whatever is worth doing at all is worth doing well" as socio economic status does not disturb them from acquiring skills for their food practical.

\section{REFERENCES}

Adamade, C.A. and Olaoye, J.O. (2014). Performance Evaluation of a Dryer for processed locust beans condiment, Agrosearch, 14(2):103 
Adebisi, T.T Opaleke, D.O and Unomah, E.N. (2015). Attitudinal Effects of Beneficiaries involvement on Lagos State Empowerment and Resources Network Programme in Catering Skills, Nigerian Journal of Education, Health and Technology Research (NJEHETR) 7(1) 1-4

Ajila, C. \& Olutola, A. (2000) Impact of Parents' Socio-Economic Status on University Students' Academic Performance. Ife Journal of Educational Studies, 7 (1): 31-39

Akinleye, S.O. and Rahji M.A. (2006). Nutritional Implications of the Demand for foods in Nigeria, Agrosearch, 8(1) 35.

Balogun, M.A., Kolawole, F.L., Joseph, J.K., Adebisi, T.T. and Ogunleye, O.T. (2016). Effect of fortification of fresh cow milk with coconut milk on the proximate composition and yield of Warankashi, a traditional cheese, Croatian Journal of Food Science Technology. 8(1):10.

Department for International Development (2004). Rural and Urban Development Case study Nigeria, 4 Study Dore by Oxford Policy Management.

Food and Agricultural Organization (2003), Feeding the cutes, Rome, Italy. FAO

Igunnu, A and Gbadebo, C.T. (2012). The Role of Home Economics in Higher Institutions in Nigeria. Journal of Agricultural Research \& Development (2nd Ed. on Food Science and Technology) 11(2), 249-263.

Kembe, E. M. (2014). Promoting Creativity and Entrepreneurship for individual and Families, Journal of Home Economics Research, 20 (1) 109-114.

Kolawole, F.L, Balogun, M.A., Opaleke, D.O. and Amali, H.E. (2013). An Evaluation of Nutritional and Sensory Qualities of Wheat Moringa cake, Agrosearch, 13(1): 87.

Lang, T., and Caraher, M. (2001). Is there a culinary skills transition? Data and debate from the UK about changes in cooking culture. Journal of the HEIA, 8(2), 2-14,

Ochonogor, E.O. and Onyebueke, D.O. (2003). Towards improving skill Acquisition in Practical by NCE Home Economics Students for Self-Reliance, Journal of Home Economics Research, 5(2): 14 $-15$

Ode, M.O., Babayeju, A.A., and Obalowu, M.A. (2012). Efficiency of Traditional Food Processing Technology in the Locality. Journal of Agricultural Research \& Development (2nd Ed. on Food Science and Technology) 11(2): 363-368.

Ogunleye, I.O. and Awogbemi, O. (2009). Methods of Preserving and improving the Quality of Locust Beans, Advanced Material Research: 62-64, 226-233 (www.scientific.net)

Okioga, C. K. (2013) The Impact of Students' Socio-economic Background on Academic Performance in Universities, a Case of Students in Kisii University College Kenya. American International Journal of Social Science 2 (2):38-46.

Olaitan, S.O. and Agushebo, O.N. (1981). Introduction to the Teaching of Home Economics, New York, John Wiley \& Sons Ltd, Pp. $15-18$.

Olusanya, J., Bala, F., Eyisi, O. and Olojola, S. (2000). Exam focus - Foods and Nutrition for WASCCE and SSCE, Ibadan University Press Plc.

Oniyama E.E. and Amoroma Asite, A. (2008). Fundamentals of Human Learning, Warri, COEWA Publisher Pp. 20-23.

Pavlov, I.P. (1902). The Work of the Digestive Glands Translated, London Charles Griffin. Pp. 28 - 30. 